\title{
Fair Pricing Regulation
}

\section{Jan Muir}

$\mathrm{S}$ ome products and services are such an important component of business and consumer expenditure that their pricing can have widespread implications for the efficiency and well-being of significant groups of business or consumers. Where firms producing such items face little or no competition, incentives exist for prices to be set in ways that compromise those interests. Consequently, governments may seek to regulate those prices to ensure outcomes acceptable to the community.

Public utilities, including water, energy and telecommunications, are traditionally regulated for such reasons. The regulators tasked with the job of setting or approving prices or price changes usually operate within parameters given to them directly by government. These rules usually require the prices to be 'efficient'. They frequently require them to be 'fair'.

Economics offers guidance as to what is meant by 'efficiency' in price setting. There is much less consensus about what constitutes a 'fair' price. Fair against what criterion? Fair to whom? There is even less consensus about the relative importance of the two criteria. If making a price fairer were also to make it less efficient, how is a solution to be reached? Are such trade-offs likely, or even inevitable?

In this paper, the idea of fairness in pricing is explored in the practical context of utility price regulation. The pricing principles and decisions of a number of Australian and foreign utility regulators are considered, and the ways in which fairness considerations are reflected in their price determinations are identified. Actual and potential conflicts with efficiency objectives are analysed. Finally, conclusions are drawn about the role of fairness in public policy more generally. The paper begins, however, by establishing the extent to which fairness is a consideration for utility price regulators.

\section{Requirements for fairness in regulated pricing}

Examination of the objectives of a small and fairly random selection of Australian and foreign utility regulators reveals that fairness figures explicitly in almost every case (Box 1). Where it does not, related notions are generally cited, including the social impact of decisions, consumer protection, equitable access, the achievement of certain 'minimal levels' of provision, or the prevention of unfair practices.

However, while the term 'fairness', or one of its synonyms, appears frequently in such objectives, it is rarely defined in specific, operational terms.

Jan Muir is a research economist who has worked in a number of government departments and agencies. The views expressed in this article are her own and should not be attributed to any other individual or organisation. 


\section{Jan Muir}

Regulators are simply required to set prices that are 'fair', 'fair and reasonable', 'fair, reasonable and non-discriminatory', 'just, reasonable and affordable' or 'equitable'.

\section{Box 1: Fairness and the Objectives of Regulators}

\begin{tabular}{|c|c|c|}
\hline \multicolumn{3}{|c|}{ Retail Services } \\
\hline Organisation & Function & Fairness Principles ${ }^{a}$ \\
\hline $\begin{array}{l}\text { South Australian } \\
\text { Water Corporation } \\
\text { (SA Water) }\end{array}$ & $\begin{array}{l}\text { Pricing of (retail) } \\
\text { sewerage and wastewater } \\
\text { services (inter alia) }\end{array}$ & $\begin{array}{l}\text { 'To make sure that South Australia has a widely } \\
\text { acceptable, fair and efficient sewerage pricing } \\
\text { system...' (SA Water 2000a:1) }\end{array}$ \\
\hline $\begin{array}{l}\text { Western Australia } \\
\text { Office of Energy }\end{array}$ & $\begin{array}{l}\text { Connection of regional } \\
\text { and remote communities } \\
\text { to regional electricity } \\
\text { systems (inter alia) }\end{array}$ & $\begin{array}{l}\text { 'Equitable access to reliable electricity service at } \\
\text { commercial rates that support the economic, social, } \\
\text { cultural and environmental structure of regional and } \\
\text { remote communities.' (WA Office of Energy, } \\
2000: 10 \text { ) }\end{array}$ \\
\hline $\begin{array}{l}\text { Victoria Office of the } \\
\text { Regulator-General } \\
\text { (ORG Victoria) }\end{array}$ & $\begin{array}{l}\text { Pricing of retail } \\
\text { electricity charges } \\
\text { (connection and usage) } \\
\text { (inter alia) }\end{array}$ & $\begin{array}{l}\text { '... to approve, on a fair and reasonable basis, } \\
\text { miscellaneous charges that may be imposed by the } \\
\text { [electricity] distribution companies... subject to a fair } \\
\text { and reasonable test'. (ORG Victoria, 2000:2 and 4) }\end{array}$ \\
\hline $\begin{array}{l}\text { New South Wales } \\
\text { Independent Pricing } \\
\text { and Regulatory } \\
\text { Tribunal (IPART) }\end{array}$ & $\begin{array}{l}\text { Maximum prices for } \\
\text { government monopoly } \\
\text { services including water, } \\
\text { electricity and urban } \\
\text { transport (inter alia) }\end{array}$ & $\begin{array}{l}\text { The Tribunal must 'have regard to ... factors } \\
\text { [including] the social impact of decisions [and] greater } \\
\text { efficiency in the supply of services ...' No guidance is } \\
\text { given concerning the relative importance of the factors. } \\
\text { (IPART, 2000:2) }\end{array}$ \\
\hline ACT Government & $\begin{array}{l}\text { Regulatory framework } \\
\text { for ACT utilities (inter } \\
\text { alia) }\end{array}$ & $\begin{array}{l}\text { 'Governments need to provide regulation [of utilities] } \\
\text { because there is a need to: } \\
\text { - ensure fair prices to consumers, } \\
\text { - } \quad \text { ensure a fair rate of return to the owners of the } \\
\text { utilities, ...' (ACT Government, 1998b:1) }\end{array}$ \\
\hline $\begin{array}{l}\text { Australian } \\
\text { Government (Minister } \\
\text { for Communications) }\end{array}$ & $\begin{array}{l}\text { Retail price controls on } \\
\text { Telstra (inter alia) }\end{array}$ & $\begin{array}{l}\text { '... protecting consumers - particularly those of } \\
\text { limited means - against paying too much for vital } \\
\text { telephone services ... special safeguards for low } \\
\text { spending residential customers.' (Alston, 1999:1) }\end{array}$ \\
\hline $\begin{array}{l}\text { UK Office of Gas and } \\
\text { Electricity Markets } \\
\text { (Ofgem) }\end{array}$ & $\begin{array}{l}\text { Retail price controls in } \\
\text { monopoly areas of gas } \\
\text { and electricity markets. }\end{array}$ & $\begin{array}{l}\text { '... remove barriers to the competitive market ... } \\
\text { [especially those faced by] disadvantaged and low } \\
\text { income customers ...' (Ofgem, 2000a: } 1 \text { ) }\end{array}$ \\
\hline $\begin{array}{l}\text { UK Office of } \\
\text { Telecommunications } \\
\text { (Oftel) }\end{array}$ & $\begin{array}{l}\text { Framework for utility } \\
\text { regulation (inter alia) }\end{array}$ & $\begin{array}{l}\text { '... the primary duty of the regulator is to protect the } \\
\text { interests of the consumer: ... access, price, quality, } \\
\text { choice and fairness'; } \\
\text { '... concepts of transparency and fairness in the } \\
\text { regulatory process'; } \\
\text { 'Regulation not only has to be fair, but has to be seen to } \\
\text { be fair.' (Oftel, } 1998 \mathrm{~b}: 2 \text { and } 6 \text { ) }\end{array}$ \\
\hline Oftel & $\begin{array}{l}\text { Telecommunications } \\
\text { market regulation }\end{array}$ & $\begin{array}{l}\text { Consumers are entitled to expect that 'all standard } \\
\text { [contract] terms are fair'. (Oftel 2000:2) }\end{array}$ \\
\hline $\begin{array}{l}\text { US Federal } \\
\text { Communications } \\
\text { Commission, (FCC) } \\
\end{array}$ & $\begin{array}{l}\text { Regulation of cable } \\
\text { television (inter alia) }\end{array}$ & $\begin{array}{l}\text { 'Consumers should expect a fair deal from their local } \\
\text { cable company ...' (FCC, 1999:2) }\end{array}$ \\
\hline FCC & $\begin{array}{l}\text { Regulation of telephone } \\
\text { subscriber line charges } \\
(\text { inter alia })\end{array}$ & $\begin{array}{l}\text { '... ensure that all Americans can afford at least } a \\
\text { minimal level of basic telephone service ...' } \\
(\mathrm{FCC}, \text { undated } \mathrm{a}: 1)\end{array}$ \\
\hline $\mathrm{FCC}$ & $\begin{array}{l}\text { Price caps for local } \\
\text { telephone exchange } \\
\text { carriers (inter alia) }\end{array}$ & $\begin{array}{l}\text { '... encourage growth in productivity ... while ... } \\
\text { ensuring that ... customers share in the benefits of } \\
\text { productivity growth ...' (FCC, 1997:4) }\end{array}$ \\
\hline $\mathrm{FCC}$ & $\begin{array}{l}\text { Universal } \\
\text { telecommunications } \\
\text { service (inter alia) }\end{array}$ & $\begin{array}{l}\text { '... quality service at just, reasonable and affordable } \\
\text { rates ...' (FCC, undated } \mathrm{b}: 2)\end{array}$ \\
\hline
\end{tabular}


Boxl: (continued)

\begin{tabular}{|c|c|c|}
\hline \multicolumn{3}{|c|}{ Wholesale Services } \\
\hline Organisation & Function & Fairness Principles $^{a}$ \\
\hline $\begin{array}{l}\text { Council of Australian } \\
\text { Governments }\end{array}$ & $\begin{array}{l}\text { Uniform national } \\
\text { framework for access to } \\
\text { gas pipelines (inter alia) }\end{array}$ & $\begin{array}{l}\text { '... provid[ing] rights of access to natural gas pipelines } \\
\text { on conditions that are fair and reasonable for the } \\
\text { owners and operators of gas transmission and } \\
\text { distribution pipelines and persons wishing to use the } \\
\text { services of those pipelines ...' (OffGAR, 2000a:1) }\end{array}$ \\
\hline $\begin{array}{l}\text { WA Office of Gas } \\
\text { Access Regulation } \\
\text { (OffGAR) }\end{array}$ & $\begin{array}{l}\text { Gas pipeline access and } \\
\text { tariffs }\end{array}$ & $\begin{array}{l}\text { '... give proper consideration to the impact ... on the } \\
\text { small consumer end of the market ... enhance } \\
\text { competition between suppliers of gas services to such } \\
\text { small consumers.' (OffGAR, 2000b:2) }\end{array}$ \\
\hline Ofgem & $\begin{array}{l}\text { Wholesale price controls } \\
\text { in monopoly areas of gas } \\
\text { and electricity markets } \\
\text { (inter alia) }\end{array}$ & $\begin{array}{l}\text { '... prevent prices being manipulated by those who are } \\
\text { able to abuse their market power.' (Ofgem, 2000c: } 1 \text { ) }\end{array}$ \\
\hline Oftel & $\begin{array}{l}\text { Regulate conditional } \\
\text { access for digital TV } \\
\text { services (inter alia) }\end{array}$ & $\begin{array}{l}\text { Prices must be 'fair, reasonable and non- } \\
\text { discriminatory'. (Oftel, undated } \mathrm{a}: 1 \text { ) }\end{array}$ \\
\hline FCC & $\begin{array}{l}\text { Regulation of cable } \\
\text { television program } \\
\text { access (inter alia) }\end{array}$ & $\begin{array}{l}\text { Prohibits unfair practices in the supply of pay TV } \\
\text { programs to cable companies, proscribing undue } \\
\text { influence and discrimination, price discrimination and } \\
\text { exclusive programming (inter alia). (FCC, 1993) }\end{array}$ \\
\hline
\end{tabular}

${ }^{\mathrm{a}}$ : Italics added

The few exceptions that exist give some insight into the intentions of those setting the objectives. In the United States, for example, '[telephone] rates are typically considered just and reasonable if they are based on cost' (Federal Communications Commission (FCC, undated b:3). Similarly, certain US (and Australian) telephone charges are required to be averaged geographically, so that the rates 'charged ... to subscribers in rural and high-cost areas shall be no higher than the rates charged ... in urban areas' (FCC Common Carrier Bureau, 1999:3). The United Kingdom requires access to digital television services to be offered at prices that 'must be fair, reasonable and non-discriminatory' in terms of 'the relationship between the costs involved in providing the service(s) and the prices offered, and ... the relationship between prices offered to others for the same (or related) services' (Oftel, undated a:15). The FCC (1999:2) considers that cable television customers are entitled to expect 'reasonable rates that fairly reflect the cost of doing business'.

Sometimes the objectives, rather than prescribing fairness, instead proscribe unfairness. The United Kingdom prohibits unfair terms in consumer contracts, the United States prohibits unfair practices in the supply of cable television programming, and the trade practices legislation of many countries contains sanctions against abuse of market power. According to the UK's Unfair Terms in Consumer Contracts Regulations 1999, unfairness hinges on whether the terms of the contract create a significant imbalance in the parties' rights and obligations under the contract to the detriment of the consumer, and whether that imbalance 
appears to amount to a dishonest intention or an absence of good faith by the business in question (Oftel, 2000:5).

Sometimes the objectives indicate to whom the conditions are supposed to be fair. In the case of retail services, consumers generally, or particular groups of consumers, are typically the target. However, the ACT Government (1998b:1) is not alone in requiring all parties to the transaction to be considered, and seeks both fair prices for consumers and a fair rate of return to the owners of utilities. In the case of wholesale services, all parties to the transaction typically figure. The Western Australian Office of Energy (2000:4)is concerned about equity among consumer groups when it states that its guiding principles include equity 'between regional and metropolitan communities, Aboriginal and non-Aboriginal communities and between new and established businesses within regional communities'. Similarly, the ACT's Independent Pricing and Regulatory Commission (1999:34) 'seeks to ensure that ACTEW's [now ActewAGL] pricing policy does not disadvantage one group of customers relative to others'.

These might seem ambitious - and ambiguous - objectives. They become more so when, as in most cases, they are required to be balanced with other objectives, including efficiency. The way in which they are applied in practice can be explored by examining the pricing decisions of the regulators involved.

\section{Fairness considerations in regulatory price setting}

Those decisions demonstrate considerable diversity of approach, as is clear from the examples of regulated retail pricing shown in Box 2. Retail pricing shows greater diversity than wholesale pricing. This is perhaps because it is at the retail level that the impact on final consumers is most obvious and consequently, where the greatest pressure exists to ameliorate any perceived unfairness in that impact. Approaches by regulators to wholesale pricing, on the other hand, tend to be more consistent and more explicitly cost-reflective.

\section{Price structures}

Cost structures are typically complex in networked services. The main costs of most utilities with network characteristics lie in providing and maintaining connection to the service. Once this distribution infrastructure is in place, provision of units of the service itself is likely to be much less costly. To a large extent, these cost structures are mirrored in the price structures seen among the regulators considered: a flat charge is made for continuing connection to the network, with per-unit charges in respect of actual consumption. This implies that higher-volume consumers will contribute more than lower-volume users, but that a minimum charge will be levied on all consumers regardless of use.

The only exception to this pattern among the regulators considered occurred in relation to South Australian sewerage charges, which contain no usage-related element. There, the estimated full cost of providing the sewerage service is simply distributed across rateable (business and residential) properties in accordance with 
1
0
0
0
0
0
0
0
0
0
0
0
0
0
0
0
0




their improved value (some exemptions and concessions apply). This results in consumers with higher property values paying more than others. If high property values are associated with greater use of sewerage and wastewater services (more occupants of the property, for example), such a system may generate an outcome consistent with higher-volume users contributing more. The charging regime is currently under review by SA Water and the South Australian Government.

Price structures that mirror cost structures do not necessarily mean that prices are cost-reflective or even cost-recovering in the strict sense. The proportion of fixed and variable costs recovered from the fixed and variable components in the prices may differ. This is typically the case in telecommunications, where the fixed (monthly line rental) component of consumer charges is usually maintained at a lower level than would be required to cover the estimated costs of network operation and maintenance, usually for reasons of affordability. However, the information available from the regulators considered did not enable the actual extent of cost-reflectiveness in the various price components to be identified.

\section{Price differentials}

Few utilities charge the same amounts to all their customers, irrespective of their ability to pay or the cost of supplying them. Consequently, price differentials arise. Most such differentials arise at the retail level and appear to address the ability to pay of different groups of consumers. The provision of concessional rates to particular categories of users (residential, low-income households, lowvolume users, pensioners) or uses (educational, religious, not-for-profit uses) is a common practice. The categories tend to be based on generalised assumptions about ability to pay, and are clearly intended as a form of benign price discrimination, aimed at ensuring affordable service to major consumer groups. Some utilities place the onus for claiming the concession on the consumer, while others extend them automatically on the basis of the status of the consumer.

Another common practice is the geographic averaging of charges. This involves the provision of service to all customers within the geographic reach of the utility at a uniform charge, or set of charges. Where geographic averaging is imposed on utilities, it is usually intended to reduce or eliminate rural/metropolitan price differentials which might be seen as compromising service access or affordability. In some cases, there may also be efficiency reasons for a utility to seek to maintain streamlined pricing schedules.

Both types of policies result in a mismatch between costs and charges at the level of individual customers. Whether they do so at the aggregate level depends on how any cost overhang associated with the price concessions is recovered. The particular circumstances of the utility itself may be an issue when a number of firms supply a particular service in the market. In the US, the generally lower level of earnings (ability to pay) of certain incumbent local telephone exchanges is used to exempt them from certain provisions under the price control arrangements (FCC Common Carrier Bureau, 1999). Generally, however, utility services are provided by a single firm and such issues do not arise. As input services, 
wholesale services are much more likely than retail services to be charged at cost, irrespective of the merits, ability to pay or other characteristics of the purchaser. Price differentials in wholesale service tend to relate to cost differentials of servicing particular customers (their location, volume of business, etc).

\section{Non-commercial service}

If a utility is required to service some of its customers at charges that do not reflect the full cost of service provision, it will seek to recover any resulting losses. Some utilities are required to recover them from other customers, by balancing lossmaking charges to high-cost customers against profit-making charges to others. This may result in some categories of customers effectively cross-subsidising others. Geographic averaging and concessional charging regimes are used to fund 'universal service' in many utilities, including telecommunications, and are likely to involve elements of cross-subsidy in many cases. ${ }^{1}$

Among the regulators considered, these methods of charging appeared to exist in some form in almost every case of retail supply. South Australia's sewerage charging system appears to have the greatest potential for implicit crosssubsidy. There, consumers occupying highly-valued properties pay more than those in lesser-valued properties, regardless of provisioning cost or consumption. The charge is effectively a tax, levied in an apparently progressive way.

There is less potential for cross-subsidy in the charging regime of the ACT's electricity and water provider (ACTEW). There, charges approved by the Independent Pricing and Regulatory Commission (IPARC) are uniform within the two broad categories of residential and business consumers, and any concessions are budget-funded rather than cross-subsidised by other consumers. Consequently, no price differentials exist within categories. ACTEW claimed in 1998 that business customers cross-subsidise residential customers, and IPARC subsequently agreed to allow some 'rebalancing' of the differential between categories (IPARC 1998:19).

Wholesale services do not tend to be provided on non-commercial terms.

\section{Interpretations of fairness}

These cross-subsidy decisions suggest certain patterns in the interpretation of fairness by regulatory price-setters. At the retail level, consideration of a customer's ability to pay appears to dominate. Underlying this concern appear to be attempts to improve the affordability of the service to lower-income consumers, those who are costly to supply or those with particular 'merit' claims (such as educational organisations or community organisations). This, in turn, is likely to be underpinned by a concern to extend affordable service to all citizens as a social

1 Cross-subsidy is defined as the provision of service to some customers at a charge which is below (avoidable) cost, with the loss recovered through higher charges to other customers. 
right. It follows that fairness is not apparently interpreted at the retail level in the strict sense of non-discrimination among customers (anonymous equity), which would tend to produce equal (cost-related) prices for everyone.

Of course, measuring a customer's ability to pay requires information, such as household income and circumstances, which may be difficult to access or analyse. Consequently, other more observable characteristics may be used by regulators as proxies. The status of customers as pensioners or other beneficiaries or as business consumers, the value of their residential or business property, or even the level of their consumption of the service in question may be sufficient to place them in a concessional category. To the extent that membership of such a category does not actually coincide with an individual's wealth or need, some individuals in those categories will not, in fact, be within the intended target group, while others outside the categories will form part of the intended target. Older people in inner-city properties with high rating values, small businesses, or wealthy people with holiday homes using services such as phones and electricity only intermittently may all be included or excluded in an unintended way by the use of such proxies. Where 'misfires' of this type occur, the objectives of the regulator in applying concessions based on such proxies in the interests of fairness will be compromised.

Fairness does not tend to be interpreted, at least at the retail level, on the basis of intensity of demand for the service (willingness to pay). This may reflect the fact that the services involved are essential services and are not generally supplied in a way that would warrant competitive bidding among intending consumers. In addition, with the exception of certain telecommunications and related services, the services tend to be homogeneous in quality and so unlikely to display differential demand patterns associated with different quality attributes. Perhaps because of such factors, price discrimination exploiting demand characteristics such as quality differentials, urgency, timeliness, lack of substitutes and so on appears uniformly absent from the utilities considered. Elements of 'user pays' approaches are certainly apparent. The use of per-unit charges for services over which the customer has considerable discretion in use is almost universal.

At the wholesale level, fairness appears to be interpreted almost without exception in terms of cost-reflectiveness. Identifying those costs may, however, be a complex and resource-intensive exercise, as experience in devising price controls for retail telecommunications services testifies (FCC, 1997; Access Economics, 1998).

\section{Fairness and efficiency}

Departures from cost-reflective pricing are clearly widespread, at least in the retail pricing of utilities. This may enable regulators to satisfy fairness objectives. However, regulators typically must satisfy efficiency objectives as well. To what extent do such decisions compromise those objectives? 


\section{Efficient prices}

In market economies, prices convey signals about value to producers and consumers and influence what is produced and consumed. Prices are regarded as efficient if they result in a community's resources being converted into a particular volume and mix of goods and services which the community values more highly than any other (allocative efficiency), and those goods and services then being distributed to those individuals and businesses within the community who value them most highly (distributional efficiency). This criterion underlies the KaldorHicks test, which considers a distribution optimal if no redistribution of resources or products could leave an individual better off, without leaving someone else worse off, after allowing for compensation of any losers by the gainers. A time element, which considers the pattern of production and distribution over time, may also be considered (dynamic efficiency). Despite the conceptual difficulties of inferring valuation from the willingness to pay of individuals who may have different opportunities, income and knowledge, and the inability of the model to deal with certain types of goods and services (public goods, and those generating external benefits and costs) and non-market arrangements (government), the logic of this approach is clear and its influence has been powerful.

Prices which accurately reflect the level and structure of production costs are essential to the achievement of such an optimal state. In particular, the relativities among prices are crucial. Prices which are maintained at a level above cost, when others are not, are likely to generate investment incentives which will draw resources away from production valued more highly by consumers, resulting in loss to the community as a whole. Prices which are too low will discourage investment and result in under-production relative to the optimum. In both cases - and depending on the responsiveness of consumption to price levels consumption is likely to be encouraged at levels which misrepresent the true value of the product or service to consumers.

In the case of utilities, cost-based pricing is likely to imply multi-part prices, with different prices charged for different network services (connection, continuing subscription, use of services) in accordance with the costs of providing those services - some would argue that as actual costs may be inflated by inefficient technology or practices, the relevant costs are those which would be incurred by an efficient operator. Cost-based pricing requires utilities to recover their costs where those costs arise, and not (deliberately) to over-recover or underrecover those costs. In its strict form, it would seem to exclude price discrimination intended to improve profitability, the geographic averaging of charges, and the cross-subsidy of particular services or particular consumer groups by others. Cost-based prices return to producers sufficient revenue to ensure continuation of supply, while ensuring that consumption occurs only if consumers value the product or service in question at least as highly as the value of the resources expended in producing it.

Where prices cannot be strictly equated to costs - for example, where the goods are subject to taxes, or where the structure of costs is such that conventional 
pricing rules (marginal cost pricing) do not enable full cost recovery - pricing principles which minimise the resulting efficiency losses have been developed. For example, the English economist Ramsey (1927) showed that the efficiency cost of recovering a given amount of revenue from the sale of a particular product can be minimised by charging rates to individual consumers or groups of consumers which are inversely proportional to the own-price elasticity of their demand for the product. While originally applied to taxation rather than pricing problems, this 'inverse elasticity rule' underpins the preferred approaches of many economists to the allocation of common costs across the various products of a utility, where it is referred to as Ramsey-Boiteux pricing. Nevertheless, even if cost-based pricing cannot be achieved, driving prices closer to costs can almost always be shown to produce efficiency gains.

\section{The Hilmer Committee's recommendations}

Cost-based pricing principles were strongly endorsed by the National Competition Policy (Hilmer) Review (1993) and now underpin the approach of all Australian governments to the regulation of utilities. The Hilmer Committee examined a number of principles which might be used to assist the National Competition Council in framing recommendations on appropriate price behaviour. It (p. 279) concluded that:

... [pricing] principles should focus on competition and efficiency concerns, rather than broader and potentially conflicting social and political goals.

The Committee recognised that such principles were likely to affect the community service obligations (CSOs) of utilities, particularly those funded by cross-subsidies. However, it concluded that improved transparency and more efficient funding of CSOs, possibly directly from government budgets, were desirable goals in themselves.

The trade-off between fairness and efficiency

A trade-off between fairness and efficiency considerations would therefore seem inevitable. Indeed, the possibility is well-recognised by regulators. The United Kingdom's Director-General of Telecommunications, David Edmonds (Oftel, 1998b) noted that:

Regulators may sometimes be pulled in two directions, to encourage competition and at the same time intervene in the market to protect consumers

Fully cost-reflective prices are unlikely to satisfy a number of fairness criteria, including the provision of services to consumers on an affordable basis, in accordance with their ability to pay. Multi-part prices which include fixed charges 
for network access, regardless of use, may in addition be considered regressive. If the charges are sufficiently high, they may either induce individuals to disconnect from the network, compromising access objectives, or will exact a substantial opportunity cost in terms of the amount of alternative consumption foregone. Similarly, attempts to charge different rates to different consumers on the basis of the relative elasticity of their demand are likely to be viewed by some as discriminatory (Bonbright, Danielson and Kamerschen, 1998:533-4).

Prices which satisfy certain fairness criteria are similarly unlikely to be considered efficient. Services made available at charges that are below cost may be over-consumed relative to their real valuation by consumers, causing resource misallocation and consequent loss to the community as a whole. Those losses will be exacerbated if external costs, such as pollution, result from consumption. The extent of both will depend on the responsiveness of the use of the service by the consumers involved to its price level. Consumers required to cross-subsidise such provision by paying relatively high prices are likely to experience the opposite effect. At the same time, the willingness of competitors to enter the market, or of investors to upgrade infrastructure, will be eroded by low prospective returns relative to other options.

The extent of the trade-off might, of course, be reduced if the means by which fairness considerations influence prices were explicitly designed to minimise the efficiency penalty. For example, affordability could be improved without distorting consumption by focusing on the flat (lump-sum) component, rather than the usage component, of the charges in a multi-part pricing regime. Similarly, particular consumer groups could be charged below-cost rates without directly penalising others if the resulting loss were funded by direct budget supplementation rather than by cross-subsidy from other products or other consumers.

Examples illustrating the relationship between fairness and efficiency considerations in particular pricing regimes may be organised into a contingency table as follows:

\begin{tabular}{|c|c|c|}
\hline & \multicolumn{1}{|c|}{ Fair } & \multicolumn{1}{c|}{ Unfair } \\
\hline Euadrant 1 & \multicolumn{1}{|c|}{$\begin{array}{c}\text { Quadrant 2 } \\
\text { Cost-reflective prices, with } \\
\text { budget-funded concessional } \\
\text { charges to targeted groups }\end{array}$} & $\begin{array}{l}\text { Cost-reflective prices with lump- } \\
\text { sum components which exploit } \\
\text { differences in the willingness to } \\
\text { pay of different consumers }\end{array}$ \\
\hline Inefficient & $\begin{array}{c}\text { Quadrant 3 } \\
\text { All components of the price } \\
\text { based on ability to pay }\end{array}$ & $\begin{array}{l}\text { Quadrant 4 } \\
\text { Geographic averaging of charges } \\
\text { involving a cross-subsidy of one } \\
\text { group of consumers by another }\end{array}$ \\
\hline
\end{tabular}


Certainly, fairness and efficiency considerations often conflict (Quadrants 2 and 3). The pricing regimes cited in those quadrants include some of those examined earlier, and encompass some which are well-known to Australian consumers. Some traditional solutions might even violate both fairness and efficiency principles (Quadrant 4). However, solutions which meet both considerations, at least on some criteria, are clearly possible.

\section{Fairness and efficiency}

The exhortations of the Hilmer Committee to use prices to focus on competition and efficiency concerns rather than broader social and political goals appear to have been heeded by Australian utility regulators. It is clear from the pricing determinations and other published material of those considered here that they now regard as inevitable a move towards more cost-reflective pricing. This assessment not only appears in the rhetoric of the regulators and the governments which set the parameters within which they operate, but is also apparent from recent pricing decisions (and reviews) themselves.

This is not to suggest that fairness considerations are to be abandoned, or regarded as mere 'side constraints' on otherwise efficient solutions. As shown earlier (Box 1), the emphasis on fairness in the extracts from the regulators' own terms of reference remains both explicit and compelling. The direction of the move appears not to be simply from the lower half of the table above (inefficient) to the upper half (efficient), but from unfair, inefficient outcomes (Quadrant 4) to fair, efficient outcomes (Quadrant 1).

A number of factors explain the shift. The first is competition. Crosssubsidies, and even differential pricing arrangements, are difficult to sustain in an environment of open competition. If, in some regions, or for some types of customers, expected revenues do not match expected costs, then the prospect of competitive entry into the market will be directly affected. As network access regimes increasingly enable competition using existing infrastructure, this is a genuine dilemma for regulators. A potential competitor will have an incentive to enter a market where revenues exceed costs, and no incentive to enter a market where costs exceed revenues. The phenomenon whereby low-cost service areas or groups are targeted by new entrants because of the profit potential has been referred to variously as 'cream skimming', 'cherry picking', or even taking the 'low hanging fruit' (National Bandwidth Inquiry, 1999:executive summary). To the extent that competition benefits consumers, then those in high-cost areas or categories will be denied those benefits. If cross-subsidies are to be retained, alternative arrangements, including direct government intervention in the form of infrastructure investment or other means, may be needed to ensure choice and new investment in high cost areas.

Another factor is a generally greater appreciation of the role of incentives in achieving desirable outcomes. For example, water and energy consumption have environmental effects. Reducing excess consumption, or consumption for lowervalue uses (such as car washing), may be desirable on environmental grounds 
alone and is also likely to extend the time before infrastructure extensions are required. If demand is, in fact, price-responsive, then charging a price which reflects the 'true' resource cost of supplying the service, rather than one which encourages and facilitates over-use relative to the optimum, is likely to bring a range of benefits.

A further factor is the desire for greater transparency in the operation of government-owned or regulated enterprises. Possibly allied to this has been recognition of the potential benefits to all consumers of achieving lower charges through more efficient decision-making.

A final factor may be renewed recognition that fairness and efficiency may be linked, rather than independent, phenomena. The former senior Treasury officer, Fred Argy (1998), argued recently that equity and efficiency are not separate attributes of a policy, and that the equity of a policy influences its efficiency, just as its efficiency might alter equity outcomes.

A more conventional approach might consider the implications of the decisions of particular individuals for the community more generally (the 'externalities'). For example, if social participation improves with access to the telephone, or if health is affected by access to water and energy, then the consequences of an individual's disconnection from that service, or even underuse due to income constraints, may be more than a simple loss of utility to that individual. The consequences may extend to loss of longer-term social and economic capability, with associated effects on families and the rest of the community, and ultimately greater welfare dependency.

\section{Conclusion}

The idea of fairness remains a compelling one in public policy. While welfare and taxation policies remain the most direct, and transparent, means of articulating and addressing equity and distributional objectives, fairness considerations extend to, and persist in, the pricing objectives of utility regulators in many countries. Those regulators take it seriously, despite the conceptual and practical difficulties of defining and applying fairness in practice. Some regulators, like the FCC's Commissioner Susan Ness and Oftel's David Edmonds, claim to weigh fairness considerations at least as heavily as other criteria as they seek to balance apparently conflicting objectives for the pricing regimes they control. ${ }^{2}$ Devising ways of satisfying government exhortations for fairness in pricing without compromising consumption, production and investment incentives, and environmental outcomes will continue to test the skills and creativity of regulators and their advisers. Increased competition and corporatisation in utility industries

2 For example, Ness claimed in a 1997 judgement that 'We have ... sought to achieve as much fairness as is humanly possible... At the end of the day, fairness to all parties and demonstrable benefits to consumers are the standards by which we will all be judged', (FCC, 1997:77). Edmonds claimed a further imperative: 'Regulation not only has to be fair, but has to be seen to be fair', (Oftel, 1998b). 
has increased the urgency of such matters and has stimulated vigorous debate in Australia, as elsewhere. Such debate can only assist in reaching better, more transparent regulation and utility prices that are perceived to be both efficient and fair.

\section{References}

ACT Government (1998a), 'Statement of Regulatory Intent for Utilities in the ACT', November.

ACT Government (1998b), 'Protecting Consumers and the Environment: A New Regulatory Framework for ACT Utilities', October.

Access Economics (1998), 'Review of Price Controls on Telstra', Report prepared for the Department of Communications and the Arts, Canberra, August.

Alston, R. Senator the Hon (1999), 'Government Retains Telstra Price Caps', (Press Release), 15 June.

Argy, F. (1998), Australia at the Crossroads, Allen and Unwin, Australia.

Bonbright, J., A. Danielson and D. Kamerschen (1988), Principles of Public Utility Rates, Public Utility Reports Inc, Arlington VA..

Federal Communications Commission (undated a), 'Federal Subscriber Line Charge', Washington DC, (Consumer News Alert).

Federal Communications Commission (undated b), 'Connecting the Globe: A Regulator's Guide to Building a Global Information Community', Washington DC, http://www.fcc.gov/connectglobe/sec6.html.

Federal Communications Commission (1993), 'First Report and Order in the Matter of Development of Competition and Diversity in Video Programming Distribution and Carriage', Washington DC, (FCC 93-178).

Federal Communications Commission (1997), 'Fourth Report and Order in CC Docket No. 94-1 (Price Cap Performance Review for Local Exchange Carriers) and Second Report and Order in CC Docket No. 96-262 (Access Charge Reform)', Washington DC.

Federal Communications Commission (1999), 'FCC Chairman Kennard Launches Cable Consumer Bill of Rights Campaign', 31 March, (News Release).

Federal Communications Commission, Common Carrier Bureau (1999), 'Competitive Pricing Division: Information Posted on Website', http://www.fcc.gov/ccb/cpd.html.

Independent Committee of Inquiry (Hilmer Chairman) (1993), National Competition Policy, Australian Government Publishing Service, Canberra, (Report).

Independent Pricing and Regulatory Commission, ACT (1998), 'Investigation into ACTEW's Electricity, Water and Sewerage Charges for 1998/99: Price Direction', May, $\mathrm{http}: / / \mathrm{www} . a c t . g o v . a u / g o v e r n m e n t / p u b l i c a t i o n s /$ policies/agreements/98iparc/. 
Independent Pricing and Regulatory Commission (ACT) (1999), 'ACTEW's Electricity, Water and Sewerage Charges for 1999/000 to 2003/2004: Price Direction’, May.

Independent Pricing and Regulatory Tribunal of New South Wales (IPART) (2000), 'What do we do?', http://www.ipart.nsw.gov.au/about.htm.

National Bandwidth Inquiry (1999), 2000-2004 Bandwidth, Department of Communications, Information Technology and the Arts, Canberra, (Report).

Office of Gas Access Regulation, Western Australia (2000a), 'About OffGAR - the Regulatory Framework', http://www.offgar.wa.gov.au/framework.htm.

Office of Gas Access Regulation, Western Australia (2000b), 'About OffGAR - the Independent Gas Pipelines Access Regulator’, http:/www.offgar.wa.gov.au/regulator.htm.

Office of Gas and Electricity Markets, UK (undated), 'Price Controls in England and Wales', http://www.ofge,.gov.uk/elarch/prices.htm.

Office of Gas and Electricity Markets, UK (2000a), 'Ofgem Publishes Plan to Secure Better Deal for Low Income Customers', (Press Release), 1 March.

Office of Gas and Electricity Markets, UK (2000b), 'Make Pricing Simple, Ofgem Tells Industry', (Press Release), 11 February.

Office of Gas and Electricity Markets, UK (2000c), 'Ofgem Issues Final Guidelines for Market Abuse Condition’, (Press Release), 31 January.

Office of the Regulator-General, Victoria (2000), 'Price Regulation - Electricity', http://www.reggen.vic.gov.au/elec_8.htm.

Office of Telecommunications, UK (undated a), 'The Regulation of Conditional Access for Digital Television Services', http://www.oftel.gov.uk/broadcast.connacc.htm.

Office of Telecommunications, UK (undated b), 'Frequently Asked Questions', http://www.oftel.gov.uk/crs/faq/page4.htm.

Office of Telecommunications, UK (1998a), 'A Fair Deal for Consumers: Modernising the Framework for Utility Regulation', Oftel Response to the Green Paper, London, May, http://www.oftel.gov.uk/feedback/urep0598.htm.

Office of Telecommunications, UK (1998b), 'The Regulators' Perspective: Does Competition Really Benefit All Consumers and What Should Be in the Government's Action Plan?' Address by D. Edmonds (Director General) to 'Putting the Consumer First' (20 May), Oftel House Magazine, http://www.oftel.gov.uk/speeches/house598.htm.

Office of Telecommunications, UK (2000), 'Telecom Service Contracts', Statement issued by the Director General, March, http://www.oftel.gov.uk/consumer/tsc0300.htm.

Ramsey, F. (1927), ‘A Contribution to the Theory of Taxation', Economic Journal March:47-61. 
Regulatory Reform Taskforce, ACT (1999), 'Draft Outline of ACT Utilities Regulatory Regime', Canberra, March.

South Australian Water Corporation (2000a), 'Sewerage Pricing Consultation', Adelaide, http://www.sawater.com.au/Hot_Data/.

South Australian Water Corporation (2000b), 'Sewerage Pricing in South Australia', Adelaide, (Discussion Paper).

South Australian Water Corporation (1999), 'Your Water and Sewerage Rating System', http://www.sawater.com.au/Customer_Centre/welcome/charges_explained.html.

Western Australia Office of Energy (2000), 'Policy for the Connection of Western Australia's Regional and Remote Communities to Western Power's Regional Electricity Supply Systems', Perth, (Discussion Document).

This is an abridged version of a forthcoming paper in the Discussion Paper series of the Graduate Program in Public Policy at the Australian National University written by the author while she was a Masters student in the program. The author is grateful for the assistance provided by Richard Mulgan, John Uhr and Marie Carney and for helpful comments from colleagues and an anonymous referee. 